\title{
Organizing for Innovation
}

\section{Organizing for Perpetual Innovation}

Given that innovative ideas are expected to be generated on a permanent basis, it is interesting to observe that among the documented firms, there were special practices in place to assure that ideas and improvements would roll off the assembly line of innovation. Such organizational practices were particularly prevalent in firms which could be classified as platformers, or those practicing and dependent on a steady stream of new product versions, or variants.

\section{Creating an Innovation Assembly Line}

u-blox had perfected a complex, globally distributed, but centrally directed, development organization that managed several hundred projects simultaneously. Of particular importance were the organizational practices the company adopted to connect the entire development effort as if it were taking place at a single location, while leaving the development nodes in place at their respective, different locations to avoid disruptions through relocation of staff.

u-blox operated 15 research and development centers across the world. Its acquisition strategy was closely linked to the need to ramp up development capacity. Starting early in its development, the company concentrated on acquiring engineering teams abroad, avoiding the acquisition of operating businesses and leaving these teams in their original locations. Relocating all of these specialists to the Swiss operations would have resulted in losing many of them. Leaving them in place meant that they could continue working where they wanted to live with their families. Some of these teams were very small, just a handful, and the largest one in Italy had a staff of about 100. The development process was coordinated by the company CEO, assisted by two co-CTOs. At any time, there were 
about 300 projects in the pipeline, 100 to 200 of them were major ones and the rest variants of others. ${ }^{1}$

Teams at u-blox would connect regularly online, discussing technology and design only, following a particular routine: Teams would always meet on the same day of the week for a given project or device. These online meetings would last for anywhere from 30 minutes to two hours. Timing was rotated such that, as an example, the Thalwil Head Office team would be on in the morning in week one, around noon in week two, in late afternoon in week three, and in the very early morning in week four. Then the rotation sequence would be repeated. Other teams in other locations and time zones would adjust accordingly. As a result, a given team would only have one inconvenient meeting time over the four-week cycle. This meeting schedule was designed so that development engineers did not have to travel extensively. Instead, it was the co-CTOs who traveled between the teams. ${ }^{2}$

maxon, another platforming company, organized itself to enter many segments based upon its product and technology platform, spending as much as 8 percent on sales on its development effort.

maxon found entry into many application areas. While originally starting out building motors for consumer applications, the segment composition was subject to constant changes and evolution, requiring adaptations and innovation on the part of the company. maxon employed about 200 specialists, mostly in Switzerland and some in Germany, and spent about 8 percent of sales on the effort. Once the company began to grow, the majority segment had been industrial robotics carrying as much as 50 percent of sales. This declined to about 20 percent in 2018. The segment then moved into robotics and automation, including transportation. Taking its place, in turn, as segment leader was medical, with as much as 50 percent of sales. The aerospace segment was also shifting from pneumatic driven to electronic driven, expanding sales opportunities. The transportation segment moved from functional mobility to system partners, as in the case of the e-bike system where maxon became industrial partner for its maxon-Bikedrive, consisting of rear motor, battery and controller. $^{3}$

For some companies, investigating, researching, and documenting their customers' activity cycle (CAC), or internal value chain, yielded the insights which stood at the beginning of innovations of important benefits to their clients. ${ }^{4}$ This practice was the basis of much of innovation at Komax.

The Komax strategy on wiring systems came with a new view towards its industry that created many growth opportunities. The company analyzed the entire wire harnessing production cycle and the time each step would take. While important from an efficiency point of view, cutting, stripping and crimping, the core activities of Komax systems, accounted for only 20 percent of the time needed to create a wire harness in the automotive industry. Routing and taping accounted for 28 and 25 percent, respectively. New insights

\footnotetext{
${ }^{1}$ Adapted from u-blox company profile.

${ }^{2}$ Ibid.

${ }^{3}$ Ibid.

${ }^{4}$ See Vandermerwe, S (1993) Jumping into the customer activity cycle. The Columbia Journal of World Business 28(2): 46-65.
} 
came from investigating the entire value chain of its customers, going beyond what had been the focus of the initial wiring systems. The strategy was now that Komax clearly wanted to expand its 'share of the wallet' of its main customers and enter value chain steps previously left to other companies. ${ }^{5}$

Komax founder Koch described the development of his equipment as stemming from his frequent visits to the assembly plants of his customers. During such visits and the close cooperation, customers were communicating their production pain points and Koch could follow up with engineering solutions. Koch emphasized simplicity in his solutions, with equipment that made production simpler, was easier to use, while at the same time meeting customers' highest engineering demands. ${ }^{6}$

To support this effort, Komax spent 8 to 10 percent of sales on innovation, research, and development, an amount that was maintained even during the 2008 financial crisis.

At the end of 2017, Komax employed about 200 professionals in the area of research of development. The majority, about 140, were located in Switzerland. Beyond the Swiss sites, Komax maintained development units in China, Germany, France, Japan and Singapore. Not included in the above numbers were about 170 development engineers who worked on customer-specific projects. The headcount in research and development had been boosted by recent acquisitions of companies with a high proportion of development specialists on their staff. These acquisitions, together with the general business expansion, increased the R\&D relevant headcount by 20 percent over previous years. ${ }^{7}$

To ensure effective and productive development, Komax deployed interdisciplinary development teams critical to its innovation strategy. Teams dealing with different processes and technologies, including experts from marketing and product management, in addition to development engineers, simplified interfaces and reduced lead times for new products.

Bachem, producer of peptides, employed a similar approach to surround its customers, the research community, and innovate around the Customer Activity Cycle.

Bachem articulated its approach as the 360-degree business model by surrounding the entire life sciences product and research process with products and services at all steps, from initial research, including pre-clinical development, clinical development and the supply of peptide drugs up to commercial scale introduction. ${ }^{8}$

When major innovations were pursued, some companies found it advantageous to keep the pursuit of new ideas apart from managing daily business and created separate teams, as DC Swiss did, or even to create separate entities, a practice Felco adopted.

\footnotetext{
${ }^{5}$ Adapted from Komax company profile.

${ }^{6}$ Ibid.

${ }^{7}$ Ibid.

${ }^{8}$ Adapted from Bachem company profile.
} 
As a small company in the tool industry, DC Swiss found it necessary to create a separate organizational space for its development units, both internal and external, to ensure development productivity and leverage a small development resource base.

DC Swiss maintained a small research and development team of five that enjoyed relatively high research output. Over five years, four new patents were granted to DC Swiss, and another two patents were pending. In 2011, the company founded Safelock SA with its own small staff of about five, organized outside DC Swiss. This spun out unit was aiming to commercialize a special design and technology, patented by DC Swiss, that came with an automatic blocking system for interior threads to be used with specially designed screws for Nano applications. Custom designed screws were also supplied by Safelock. Among the benefits of this screw system were connections that did not require chemical additives, such as glue. This was important since many customers still added glue to the fastening of screws. 9

In 2008, when Felco, the maker of manual agricultural shears, decided to enter the space for cordless portable power tools, the company felt that an entirely separate organization was needed and set up FELCO Motion as a separately incorporated firm.

As cordless battery-operated tools started to be a must for the professional users, Felco decided to launch a strategic project, to develop its own line of portable power tools in house. After an intensive study of the market potential and the investment needed, a green light was given by the owners. Two years later, a separate company, FELCO Motion was born. Its main mission being to develop, industrialize and assemble the entire new range of Felco brand battery-operated pruning shears. To underline this, the board appointed the former $\mathrm{CCO}$ of Felco as CEO of the new company, who was to report directly to the board and not to Felco management. Besides, FELCO Motion was housed in a distinct part of the Felco manufacturing complex. To answer this challenge, the new company hired about ten micro technicians and electronics specialists. FELCO Motion maintained its own small production, assembling and distribution through the Felco network. There was frequent contact with Felco management, of course, aided through co-location of the operations. ${ }^{10}$

\section{Entering into Customer Partnerships}

Given the small size of most of the documented firms, entering into customer partnerships for the development of new products, or processes, was essential to leverage limited resources. Effective partnerships reduced technology and market risks and, in many ways, extended the available resources to be invested by SMEs.

These collaborations can, and did, take many forms. At LEM, it was part of the company beginnings. Collaborations were woven into the daily business life at Bachem; for FISBA, they took the form of an OEM-type relationship; at Felco, the partnership involved a new product line; for Thermoplan, the partnership was

\footnotetext{
${ }^{9}$ Adapted from DSC Swiss company profile.

${ }^{10}$ Adapted from Felco company profile.
} 
entered with a lead customer, as was the case with maxon. In the following section, some background will be provided on each of these types of partnerships.

Without the co-invention approach, developed by LEM founder Etter early on, the company might not have gotten off the ground so fast and so easily.

Learning from failures to convince companies to accept their technical inventions, LEM founder Etter was looking for well-known companies that might be interested in co-inventing and would co-develop a complete working system and use it themselves. They would become the launch customer, indirectly prompting others to adopt the new system as well. The local Sécheron company, with whom LEM was collaborating, introduced LEM to the French TGV train builders triggering in return an introduction to GE in the US and to the Chinese railways, which resulted in many other opportunities for applications. Railway and transportation applications became an important user segment for LEM, although over the years it was eclipsed by other segments. ${ }^{11}$

The customer partnership practices at Bachem covered custom-made products only, as the catalog business contained standard products.

A key element of Bachem's partnership with key customers were long-term supply agreements that could stretch over as many as 15 years. Multiple co-operations were also entered for the development of pharmaceutical products, such as with GlyTech of Japan in 2013, that led to the successful co-development of interferon B-1a up to industrial scale production, once interferon B-1a was approved for the treatment of multiple sclerosis. To the pre-clinical development teams of biotech and pharmaceutical companies, Bachem was able to offer custom-made peptides for the extensive panels needed in the process of further refining target compounds, involving close partnering with life sciences companies. During clinical development, when the target compound had been identified, Bachem engaged in close collaboration around the optimization process needed for the development of formulations, scale-up of production and eventual validation. In the launch phase of a new drug project, Bachem was able to act as the contract manufacturing organization, providing manufacturing up to full-scale volumes on a flexible basis, particularly important to customers in the early launch phase when required volumes were difficult to forecast. ${ }^{12}$

FISBA, producer of micro-optics, relied on a long-term OEM relationship to produce exclusively for a German partner. The exclusive partnership lasted about 50 years.

In 1965, FISBA initiated a cooperation with KARL STORZ, a large German endoscope producer, for which it exclusively produced micro-optics. A modern endoscope must provide a brilliant image of hidden body cavities. The key parameters to be taken into account were light intensity, depth of focus, magnification, contrast and resolution. FISBA served as the 'extended work bench' and strategic supplier of micro-optics for KARL STORZ until 2016. The focus was on design, which has always been the strength of FISBA. For instance, the introduction of the rod lens system created the basis for optimal image transmission in endoscopy, allowing a highly realistic image of the surface and

\footnotetext{
${ }^{11}$ Adapted from LEM company profile.

${ }^{12}$ Adapted from Bachem company profile.
} 
structure of internal organs to be produced. This lens system has been continuously advanced and still sets standards worldwide. ${ }^{13}$

Additionally, FISBA collaborated with the European Space Agency (ESA).

Since the late 1980s, FISBA had been participating in a series of space projects run by the ESA. The company developed micro-optics for several space missions. The space business contributed less than $1 \%$ of FISBA revenues and was generating marginal profits but, through these projects, FISBA was able to generate new knowledge and develop technologies which would later be used in commercial applications. ${ }^{14}$

Despite these external collaborations, FISBA always placed a high value on internal technology and R\&D. Some CHF 3 to 4 million were invested every year in $R \& D$, and 35 out of 350 employees worked in research and development. In addition, between two to five new patents were filed every year, boosting the overall patent pool to a total of 25 to 30 patents.

FISBA and Acutronic were not the only companies collaborating with space agencies. maxon had engaged in such collaboration since the early 1990s.

When the US space agency NASA contacted maxon inquiring if its motors could withstand very low temperatures, few could imagine that this would lead to a business relationship that would literally put maxon on the map - and on Mars. It took several years, and visits to Sachseln, until the project was completed, and NASA's 'Sojourner' mobile rover landed on Mars in July 1997, powered by eleven maxon motors. With the nomination of maxon as a preferred supplier, the company gained worldwide notoriety for the reliability and quality of its drives. In 2004, NASA landed two more rovers on Mars, 'Spirit' and 'Opportunity', each equipped with 39 maxon motors. maxon motors were also on the 'Cassini' satellite exploring Saturn, and new projects with NASA were planned. Equally, maxon collaborated successfully with other space agencies. ${ }^{15}$

Felco accepted entering a partnership with Stihl, a large German company in related fields and interested in Felco's technologies; this also involved a collaboration in distribution and sales.

In 2014, Felco entered a wide-ranging partnership with Stihl of Germany, a world leader in power saws and lawn care machinery. Stihl, who was into cutting big trees, wanted access to Felco technologies and products for cutting small trees and branches. The board management agreed to a partnership that offered important benefits to both companies. Stihl obtained access to Felco's various technologies on an OEM basis and, in return, Felco gained access to Stihl's distribution network. Not satisfied with this trade alone, Felco also asked for, and obtained, access to Stihl's 40,000 point-of-sales worldwide for its tools. The products marketed through Stihl were being co-branded but were produced by Felco and FELCO Motion. ${ }^{16}$

\footnotetext{
${ }^{13}$ Adapted from FISBA company profile

${ }^{14}$ Ibid.

${ }^{15}$ Adapted from maxon company profile.

${ }^{16}$ Adapted from Felco company profile.
} 
Few companies used the cooperation with a single customer to the extent that Thermoplan did. Having already made the transition from installing institutional kitchens to developing and supplying automated modules for milk foaming and cream beating, Thermoplan leveraged an intensive cooperation with Starbucks, the world's largest coffee shop chain, to launch a fully automatic coffee machine that was to grow the company more than tenfold in a decade. The connection with Starbucks was made at a fair in 1997 where Thermoplan, a newcomer to the field of professional coffee machines, first showcased its newly developed model, prompting Starbucks to include Thermoplan in their search for new machines.

\begin{abstract}
After an evaluation of several machine suppliers, Starbucks included Thermoplan as one of three suppliers in its six month's long testing phase, allocating a site in Vancouver, Canada to Thermoplan. Over this pilot testing phase, Thermoplan managed to constantly adjust and improve its machine, impressing Starbucks both with its flexibility and machine performance. In 2000, Thermoplan signed an exclusive, long-term, global supply contract with Starbucks for all its coffee shops. Remembering the negotiations with Starbucks, CEO Steiner recalled that the contract terms went on and on over many pages and included considerable restrictions for Thermoplan on sales to other customers. For Thermoplan, just two things mattered, the rest was viewed as 'pure legalese'. First, the purchasing terms were in CHF and not in USD, eliminating any currency risk. Second, payments were to be made within ten days after invoicing. This was critical for a company that was sourcing most components from small local suppliers and that way could provide financing to them. ${ }^{17}$
\end{abstract}

That there is a risk in concentrating on one dominant customer was driven home to Thermoplan during the financial crisis of 2008-2009. By that time, the Starbucks business amounted to 70 percent of Thermoplan sales. In the middle of the crisis, Starbucks canceled all its orders, a decision that was alleviated only in 2009 when Starbucks resumed orders at a lower level, allowing Thermoplan to maintain its local component supply chain.

Thermoplan realized that depending on one single account for 70 percent of its sales was far too risky. Around 2010, Thermoplan began systematically to recruit other long-term partners. The UK-based chain Costa Coffee was developed as a partner for custom-made machines. Thermoplan developed a machine for coffee capsules for Nespresso. Partnerships for non-coffee machines were also in development. ${ }^{18}$

The experience of the above-cited companies demonstrates both the benefits and the risks of entering into close customer partnerships. These relationships are most helpful when they lead to new products that can be exploited widely and without restrictions. When they are tied to some form of exclusivity, conflict or risks invariably arise until the company entering into those relationships can regain commercial control.

\footnotetext{
${ }^{17}$ Adapted from Thermoplan company profile.

${ }^{18}$ Ibid.
} 


\section{Business Model Innovations}

Few strategy topics have received as much attention over the past decade as the issue of business models. For the purpose of this book, the authors have adopted some of the original ideas presented by Jane Linder and Susan Cantrell, both with Accenture, in 2001. ${ }^{19}$ Following those earlier ideas, the authors have refrained from using business model as a substitute term for strategy and use examples from their research only if they have shown some substantial change among paying customers, or the activity for which payment is received.

Most of the companies covered by this research follow a traditional business model: They produce products and sell them to an established list of customers, receiving payments for manufactured products. A few, such as Oetiker, Sylvac, Selectron, and Plaston, started out as subcontractors to larger firms before converting to OEM players or moving on with their own brands. Given that these companies are all manufacturers, the make and sell commercial model applies to all of the companies, with a few exceptions involving later innovations.

With many of the documented firms looking back on a long history, it should come as no surprise that some of the companies found that the original business model did not ultimately survive or that additional new business required a different business model. Some of these changes, such as at Cendres + Métaux $(\mathbf{C}+\mathbf{M})$, were cumulative, which means new business models were added to the original one as the company ventured into new segments, essentially ending up with four different models supported in parallel.

That the business model adopted when $\mathbf{C + M}$ was founded would not be suitable for the many new businesses to be added later was understandable and to be expected. To permanently adapt and fine-tune the business model over time, however, would be a challenge for any organization.

At the outset, $\mathrm{C}+\mathrm{M}$ recycled precious metals for clients and resold the refined materials. This model was dominant for roughly the first 40 years of the company's history. As the company evolved, the recycling model remained, but over time became less dominant without ever completely disappearing, as other models were added.

Starting during the first third of the 1900s, the company became involved as a sub-contractor of manufacturing components for the watch industry, still its main customers, during the first 75 years of its history. The sub-contracting model was enhanced by also assuming responsibility for parts and modules, getting involved in design once the materials used went beyond gold and silver to ceramics, titan and steel. For some customers, $\mathrm{C}+\mathrm{M}$ also provided modules and assembly services, taking over an ever-larger role and ever more responsibility.

Expansion into medical and dental markets brought about new tasks and challenges. Added to the material processing and manufacturing steps were new requirements dictated by the dental and medical industries. Clients changed, with dental technicians dominating first, but as the company also became a contract manufacturer and outsourcing partner, new activities

${ }^{19}$ Linder J, Cantrell S (2001) Changing business models. Working paper, Accenture. 
such as clean room, packaging and logistics were added. Adopting the role of full partner to many medical and dental organizations, $\mathrm{C}+\mathrm{M}$ also needed to adjust manufacturing, running dedicated cells and processes for individual clients. At the end of this process stood the role as an integrated partner for a full range of customer specific products supplied to fit into complicated logistics chains.

Most of these steps meant that $\mathrm{C}+\mathrm{M}$ acted in the role of white label supplier where the final user would not know who produced the product. Success in both the dental market, and plans for entering the dialysis segment, opened up the opportunity to act as brand-name supplier, shipping products under $\mathrm{C}+\mathrm{M}$-owned brand names. ${ }^{20}$

Needless to say, managing separate business models under one corporate roof is challenging since the requirements for the recycling, the watch components, and the dental and the medical business operations meant adopting different business models. $\mathrm{C}+\mathrm{M}$ was a rare example among the firms in the sample.

It is worthwhile to review the experience of Geistlich, a company which made the change from industrial bone processing for industrial and construction customers, adhered to for decades, to life as a supplier of specialty bone materials for medical purposes, thereby changing all the elements of the Geistlich business model, from distribution to selling and research, as well as changing all internal processes.

In line with the new orientation of the company, a completely different business model was required. Geistlich Pharma customers were now dental surgeons located all over the world, radically different from industrial users of adhesives located largely in Switzerland. In order to reach dental surgeons, the company put its emphasis on direct sales and meeting customers at conferences, thus conducting its business without a formal sales force. At those conferences, surgical procedures could be demonstrated.

To support the educational effort that went into communicating the use of biomaterials for bone enhancement, the Osteology Foundation was created in 2003. A second foundation, the Osteo Science Foundation, was established in 2013 and also supported by Geistlich.

In addition, subsidiary companies were built in key markets. With 95 percent of production exported to some 90 countries, the role of these companies was to provide distribution to the well-defined target market of dental surgeons. Ten such companies were set up.

With research becoming fundamental to the development of Geistlich biomaterials, the company established and maintained a large network of scientists across more than 100 universities spread all over the world. In house, the company maintained a highly skilled group of experts in the field of bone regeneration and collagen use, prompting some in the field to refer to Geistlich as the 'Tissue Engineers'. ${ }^{21}$

In a true break from the traditional business of making tools and selling them through distributors, or resellers, Fraisa moved to a Tool Care model where the company collected used tools and resold them as refurbished tools, clearly a change in business model with the company now getting paid for a different activity.

\footnotetext{
${ }^{20}$ Adapted from $\mathrm{C}+\mathrm{M}$ company profile.

${ }^{21}$ Adapted from Geistlich company profile.
} 
Fraisa came to the conclusion that only added services would protect its business from Asian knock-off competition. Copying at first some strategies adopted by the big German company Wirth, Fraisa rolled out its Tool Care model involving tool inventory management to make machining workshops more efficient. The next step led Fraisa into the tool refurbishing business and was a major break from the reseller model. If professionally done, refurbished tools could be used two or three times before the end of tool life. However, this could not be accomplished either by the customers or on customer premises, mandating an external service operation. Fraisa established special collection boxes for used tools on customer premises, provided pick-up with its own trucks and, in 2000, it acquired a specialized company in Langnau i.E. for the servicing of collected tools. This service was also extended into Germany, a major market for Fraisa. ${ }^{22}$

The idea of getting into servicing and being paid for it as a freestanding business activity was also picked up by Jura Espresso Machines.

At its main site in Niederbuchsiten, Jura created an exhibition entitled "Jura World of Coffee" that attracted thousands of visitors each year. Also located on the site was a new service center where consumers could bring in their own machines, have them electronically diagnosed on the spot and scheduled for any necessary repairs. For customer ease, there were 24-hours drop-off and pick-up locker facilities. The company was still experimenting how to make this extensive service capability a self-supporting part of the company. ${ }^{23}$

LNS, producer of bar feeders, changed its business model by adding different products to its line, moving from single line marketer to multiple machine marketer and establishing a one-stop service for its customers. The company remained with its established segments, but by adding other related peripherals that worked in the same manufacturing environment as its original bar feeders, LNS extended its business model.

LNS left the OEM CNC machinery suppliers selling their equipment directly to their customers market. LNS concentrated instead on selling its peripherals directly to the installed machine base. The global coverage of sales and service was patterned after the strategy of Mazak, a successful Japanese OEM machine supplier. In 2011, the strategy of becoming a one-stop shop became formalized. LNS thus offered a range of bar feeder models for different levels of automation, as well as a range of chip collection systems, all of them engineered to plug-compatibility for a full range of OEM CNC machinery suppliers. ${ }^{24}$

When a major innovation takes place, a company can impose an entirely new business model on an entire industrial sector. Such an impact was the result of Bachem entering the field of peptides used in pharmaceutical research.

Ever since its founding in 1971, Bachem had taken the lead in creating a business model that was new in the life sciences industry. Up to that time peptides had been produced internally by each company; Bachem created the market for a merchant supplier doing business with

\footnotetext{
${ }^{22}$ Adapted from Fraisa company profile.

${ }^{23}$ Adapted from Jura company profile.

${ }^{24}$ Adapted from LNS company profile.
} 
multiple life sciences customers. Over time, the peptide supply moved from being almost entirely captive to about 70 percent merchant based, a major change for the industry. ${ }^{25}$

For some companies, the new business model could be an add-on propped up on the existing, dominant model and not represent a step-out from a business management perspective. Two such innovative examples were conveyed by Caran d'Ache and by Felchlin.

Using the internet and social media became ever more important for Caran d'Ache. The company believed that 80 percent of the population would look up products on-line and then go to a store. The company therefore opened its own e-shop. Overall, Caran d'Ache was investing about 10 percent of sales in marketing activities. As an extension of this shift in consumer behavior, Caran d'Ache was building concept stores. The company came to the conclusion that its own retail store was needed in Geneva. This was as much for marketing as it was to understand the retail environment by engaging directly with customers. Feedback meetings were held on a monthly basis between retail and marketing staff. The Geneva store was run by Caran d'Ache employees. Other concept stores were franchised with partners in Berlin and Tokyo. ${ }^{26}$

Felchlin, maker of chocolate couvertures for pastry chefs all over the world, wanted to create a school for chefs. The result was the creation of Condirama as described below. Felchlin's base business of supplying chocolate couvertures to discerning chefs remained squarely a B2B business with the company refraining from selling directly to consumers, with one exception: its factory store where select products were sold to local residents on a very limited basis.

Felchlin marketed complex products that required considerable explanation for the selection of tastes and how to apply them. For this purpose, Felchlin created Condirama in 1988, located in Schwyz, equipped to show professionals how to do it right. The school attracted 1000 to 1500 visitors annually. Swiss customers enrolled in one-day courses and did not require overnight stays. International customers, however, enrolled into one-week courses requiring a residential period. Condirama was run as a cost center. Swiss-based customers, when ordering products, received points, a form of frequent flyer miles, which then could be used to gain access to the courses at no additional cost. International customers, or users, were typically sponsored by their importers for the trip and Felchlin covered local food and lodging during their stay. ${ }^{27}$

\section{Resting on Laurels Not Allowed!}

For SMEs to remain successful, the companies needed to accept that having a good idea once is simply not good enough. A steady stream of innovations is required, and therefore, it is crucial that a company is set up in a way that such new ideas are captured and brought to market as a matter of course. Adopting product platforms

\footnotetext{
${ }^{25}$ Adapted from Bachem company profile.

${ }^{26}$ Adapted from Caran d'Ache company profile.

${ }^{27}$ Adapted from Felchlin company profile.
} 
can be an enormous aid in generating new ideas, because it focuses the entire company on the process of maintaining and refreshing the platform elements. The active attention of thinking in terms of CAC provides a company with that same discipline. And finally, as has been pointed out, the deliberate innovation around a business model can release additional innovative energy in a company and its staff. The SMEs featured in this research did not set out one special Monday morning to search for new ideas. These ideas were automatically, and at regular intervals, brought forward as per usual, rather than being exceptions to a rule.

Open Access This chapter is licensed under the terms of the Creative Commons Attribution 4.0 International License (http://creativecommons.org/licenses/by/4.0/), which permits use, sharing, adaptation, distribution and reproduction in any medium or format, as long as you give appropriate credit to the original author(s) and the source, provide a link to the Creative Commons license and indicate if changes were made.

The images or other third party material in this chapter are included in the chapter's Creative Commons license, unless indicated otherwise in a credit line to the material. If material is not included in the chapter's Creative Commons license and your intended use is not permitted by statutory regulation or exceeds the permitted use, you will need to obtain permission directly from the copyright holder.

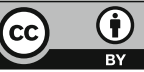

